\title{
A Near-Death Experience Among the Mapuche People
}

\author{
Juan S. Gómez-Jeria, Lic. Q. \\ University of Chile
}

ABSTRACT: This paper describes a possible near-death experience (NDE) among the Mapuche people of Chile. The individual reporting the experience was in a cataleptic-like state for two days, the experience itself occurring at the end of this period. Some common features of NDEs, such as encounters with deceased people and being sent back, are present, together with clear evidence that past and present cultural environment shape in part the content of mental experiences.

Most near-death experiences (NDEs) are influenced by culture (Counts, 1983; Pasricha and Stevenson, 1986), despite some cases in which personal or cultural beliefs clash with mental events (Abramovitch, 1988). In this paper I report a possible NDE showing that religious beliefs and historical events contribute to the individual's report of his experience. As this NDE occurred among the Mapuche people, a brief account of their history and religious beliefs is pertinent.

The Mapuche ("land people," from "mapu"=land and "che"=people) inhabited the central and southern regions of Chile and Argentina when the Spanish conquerors arrived. Their heroic resistance against the Spanish, which lasted for 350 years, ended with the annexation of the last remaining Mapuche territory to the Chilean state in 1882

Juan S. Gómez-Jeria, Lic. Q., is Associate Professor of Chemistry at the University of Chile. This work was funded in part by the University of Chile (DTI Project Q-3064). The author thanks Editorial Andrés Bello for permission to translate the near-death account into English. Reprint requests should be addressed to Lic. Gómez-Jeria at the Universidad de Chile, Facultad de Ciencias, Departamento de Quimica, Casilla 653, Santiago, Chile. 
(Encina, 1989). Each individual Mapuche community identifies itself as Mapuche, calling other Mapuche communities Huilliches ("people from the south"), Puelches ("people from the east"), Ranculches ("people of the reed-grass"), etc.

The Mapuche believe that life continues beyond death, in a body that is an exact double of the body during life, subject to the same needs and feelings as the body during life and preserving all the characteristics of the individual at the time of death. When death arrives, this double separates from the physical body and enters the Am phase, in which it remains attached to the people and places the dead person knew. About a year later, the Am goes to the spirit region and becomes a Pulli. The Pulli continues to take care of the deceased person's living relatives and friends. The Mapuche incorporated the Pulli into the Pillan, an entity that does not correspond to a god or a demon but rather to an ancestor. Each clan and each tribe has its own Pillan, which may be male or female.

\section{The Testimony}

The testimony reported here was taped on May 13, 1968, by Mrs. M. Calvo de Guzmán near Lake Calafquén, which is surrounded by the Villarica, Quetropillán, Choshuenco, and Lanín volcanoes. This story is interesting because it features some characteristics of NDEs and is culturally shaped by past historical events and Mapuche beliefs. This account was published in Spanish under the title, "The Man Who Died and Went to the Volcano" (Calvo de Guzmán, 1992, pp. 47-48). The English translation presented here is mine:

Well, here it is said that no living being goes to the Pillan, but all the souls of dead people do. Here there is an old man called Fermin. He was dead for two days, and it is said that he went into the volcano and came back. He said that all his dead acquaintances, his own parents, his children, his wife, and other children that he did not know were all in there. There was also a German gentleman reading and writing in big books. When the German saw him, he asked what he wanted.

"I am following my son," said the old man.

"What is his name?" asked the German gentleman.

"Francisco Leufuhue."

He called the guard and ordered him to inform Francisco. The guard climbed by a ladder and cried: "Francisco is being called!"

And a distant voice answered from that place, but it was impossible to understand what it said.

Then he passed through a wooden gate, and the gate was noisy. He passed the next gate, which also made a noise. He passed through 
another, and after the fourth, Francisco arrived at the German gentleman's table, who said to him: "Your Dad is looking for you."

Old Fermin approached his son and greeted him, saying: "You will receive me because I do not wish to live any more where I am living now. I am following you; I do not want to stay any longer on Earth."

"No, Dad," said Francisco, "it is not time for you to arrive here by your own will. When the time comes, I myself shall go to the side of the house to look for you. Then you will come. Now, go away."

At this moment, Don Fermin woke up and opened his eyes. He found his wife crying and asked her why.

"Because you had died," she said. "For two days you were dead."

"I am alive," answered Fermin, "and I went to the volcano. I saw all the dead people who are kept in there. I was with my son and with my grandparents. They are all together and they are very happy. They are waiting for me there, but it is not time yet."

\section{Discussion}

According to this testimony, the individual was dead for two days. It is obvious that he was not; but it can reasonably be assumed that he was in such a state that his relatives and friends believed him to be dead. His NDE, or NDE-like experience, must have occurred during the latter part of those two days, given that at the end of the experience the individual opened his eyes. This period in which he was in a cataleptic-like state without food or water for almost two days before the NDE was sufficient to provoke abnormal cerebral function, which fits nicely with the neurobiological model for NDEs proposed by Juan Saavedra-Aguilar and myself (1989).

Like most NDErs, Fermin found deceased people that he knew, together with other people. Note that there was no change in age or appearance of the people he met. It is also of interest that Fermin was "sent back" to life not because of a mistake or by messengers, but because his time had not yet come. This is in perfect agreement with Mapuche beliefs (Encina, 1989).

The "German gentleman" seems to be a very interesting feature. Why not a French, British, or, more likely, Spanish gentleman? The answer is that the part of Chile in which Fermin lived was subjected to strong German colonization beginning around 1850. Also note that the German gentleman was writing, in spite of the fact that the Mapuche culture has no writing. This shows that past and present cultural environments contribute in part to shaping the content of mental experiences.

This report supports the increasing data suggesting that NDEs seem to be composed of several independent processes that do not always 
appear together. For this reason it would be helpful for someone with access to a large data base of NDE reports to publish information about the different combinations of features that appear in NDEs, such as noises, out-of-body experiences, tunnels, and encounters with other beings. This information would clearly help us to construct scientific models to explain NDEs.

\section{References}

Abramovitch, H. (1988). An Israeli account of a near-death experience: A case study of cultural dissonance. Journal of Near-Death Studies, 6, 175-184.

Calvo de Guzmán, M. (1992). Secretos y tradiciones Mapuches [Mapuche secrets and traditions]. Santiago, Chile: Editorial Andrés Bello.

Counts, D. A. (1983). Near-death and out-of-body experiences in a Melanesian society. Anabiosis: The Journal of Near-Death Studies, 3, 115-135.

Encina, F. A. (1989). Historia de Chile [History of Chile]. Santiago, Chile: Editorial Revista Vea.

Pasricha, S., and Stevenson, I. (1986). Near-death experiences in India: A preliminary report. Journal of Nervous and Mental Disease, 7, 205-222.

Saavedra-Aguilar, J. C., and Gómez-Jeria, J. S. (1989). A neurobiological model for neardeath experiences. Journal of Near-Death Studies, 7, 205-222. 